\title{
Incidence, mortality and survival of bladder neoplasms in the Czech Republic in the period 1977-2017: a time trend analysis
}

\author{
Incidence, mortalita a přežití novotvarů močového měchýře \\ v České republice v letech 1977-2017: analýza časových trendů
}

\author{
Pehalová L. ${ }^{1,2}$, Krejčí D. ${ }^{1,2}$, Büchler T. ${ }^{3}$, Janošek J. ${ }^{1}$, Dušek L. ${ }^{1,2}$ \\ 1 Institute of Biostatistics and Analyses, Faculty of Medicine, Masaryk University, Brno, Czech Republic \\ ${ }^{2}$ Institute of Health Information and Statistics of the Czech Republic, Prague, Czech Republic \\ ${ }^{3}$ Department of Oncology, First Faculty of Medicine, Charles University and Thomayer Hospital, Prague, Czech Republic
}

\begin{abstract}
Summary
Background: Bladder neoplasms represent a significant disease burden in the Czech population. This study aimed to perform a complex time trend analysis of incidence, mortality, and survival of 76,505 patients with bladder neoplasms based on the Czech National Cancer Registry for 1977-2017. Materials and methods: The time trends of incidence and mortality were evaluated using the joinpoint regression. The relative survival and Cox proportional hazards model were used for survival analysis. Results: After 2004, a significant annual decrease by $1.9 \%$ in the incidence of malignant tumors of the bladder (C67) was observed, accompanied by a sharp annual increase in the incidence of in situ bladder cancer (D090) by $16.9 \%$. For mortality from malignant tumors of the bladder, a significant decrease by $1.4 \%$ annually was detected after 1998. The decline in both incidence and mortality was most pronounced in the below- 65 years age group and in patients with a localized stage at diagnosis. While a significant decline in both incidence and mortality was observed for the first primary malignant tumors of the bladder, both these measures increased for malignant tumors of the bladder as subsequent primary neoplasms. The five-year relative survival of patients with malignant tumors of the bladder increased from $52.1 \%$ in $1990-1993$ to $62.3 \%$ in $2013-2017$. However, comparing the periods 2003-2007 and 2013-2017, a decrease has been observed. Conclusion: The decrease in the incidence and survival of malignant tumors of the bladder in the recent period is in particular caused by improved detection of in situ bladder cancer and classification changes. Other reasons for the decreasing survival include the increasing age at diagnosis, the growing number of subsequent primary neoplasms, and the increasing proportion of smokers among patients.
\end{abstract}

Key words

malignant tumors of the bladder - in situ bladder cancer - time trends - incidence - mortality survival - subsequent primary neoplasms - Czech National Cancer Registry
The authors declare they have no potential conflicts of interest concerning drugs, products, or services used in the study.

Autoři deklarují, že $v$ souvislosti s predmětem studie nemaji žádné komerční zájmy.

The Editorial Board declares that the manuscript met the ICMJE recommendation for biomedical papers.

Redakční rada potvrzuje, že rukopis práce splnil ICMJE kritéria pro publikace zasílané do biomedicínských časopisů.

$\equiv$

RNDr. Lucie Pehalová Institute of Health Information and Statistics of the Czech Republic Palackého náměstí 4

12801 Prague

Czech Republic

e-mail: Lucie.Pehalova@uzis.cz

Submitted/Obdrženo: 27. 5. 2021

Accepted/Přijato: 22. 8. 2021

doi: 10.48095/ccko2021467 


\begin{abstract}
Souhrn
Východiska: Novotvary močového měchýře představují významnou zdravotní zátěž české populace. Cílem naší práce bylo provedení komplexní analýzy časových trendů incidence, mortality a přežití 76505 pacientů s novotvary močového měchýre na základě dat Národního onkologického registru České republiky za období 1977-2017. Materiál a metody: Časové trendy incidence a mortality byly hodnoceny metodou joinpoint regrese. K hodnocení přežití bylo využito relativního přežití a Coxův model proporcionálních rizik. Výsledky: Po roce 2004 dochází k významnému poklesu incidence zhoubných novotvarů močového měchýře (C67), a to o 1,9\% ročně a naopak k prudkému nárůstu novotvarů in situ o $16,9 \%$ ročně. Pro mortalitu na zhoubné novotvary močového měchýř byl detekován významný pokles o 1,4 \% ročně již po roce 1998. Pokles incidence a mortality byl nejvýraznější ve věkové skupině do 65 let a u lokalizovaného stadia onemocnění. Zatímco u prvních primárních zhoubných novotvarů močového měchýře dochází k významnému poklesu incidence i mortality, u zhoubných novotvarů močového měchýře diagnostikovaných jako následné primární novotvary je stále patrný nárůst. Pětileté relativní přežití pacientů se zhoubnými novotvary močového měchýře se zvy̌šilo z 52,1 \% v období 1990-1993 na 62,3 \% v období 2013-2017. Avšak při srovnání období 2003-2007 a 2013-2017 pozorujeme klesající charakter. Závěr: Pokles incidence a přežití pro zhoubné novotvary močového měchýře v posledních letech je způsoben především zvýšenou detekcí novotvarů in situ a změnami v klasifikaci. Klesající přežití rovněž souvisí s rostoucím věkem při diagnóze, narůstajícím počtem následných primárních novotvarů a rostoucím podílem pacientů s kouřením v anamnéze.
\end{abstract}

\title{
Klíčová slova
}

zhoubný novotvar močového měchýře - novotvar in situ močového měchýře - časové trendy - incidence - mortalita - prežití - následné primární novotvary - Národní onkologický registr České republiky

\section{Introduction}

Malignant tumors of the bladder (MTB) are the $12^{\text {th }}$ most common malignancy and the $15^{\text {th }}$ most frequent cause of death among malignant neoplasms worldwide [1]. In 2018, 549,393 new cases were diagnosed and 199,922 patients died of this disease globally. Literature shows a higher burden of the disease in developed countries: a positive correlation between the age-standardized incidence and human development index as well as the gross domestic product have been reported [2-4]. The main risk factors for developing MTB include smoking of tobacco products, occupational exposure to aromatic amines or polycyclic aromatic hydrocarbons, infection with Schistosoma haematobium, and genetic predisposition [5-9].

The incidence, mortality, and survival are the three most widely used parameters for monitoring the progress in oncology. The time trend analysis of these parameters has become an integral part of the healthcare quality evaluation [10]. The results of published studies evaluating time trends related to bladder neoplasms (BN) differ greatly among countries $[2,4,11-15]$. The greatest differences can be observed for incidence and survival; the trend of decreasing mortality is observed in most countries. The comparison of time trends in $\mathrm{BN}$ is nevertheless a complex task, in particular due to the changes in classification and coding over time, which are not unified across registries. A study on BN classification demonstrated principal differences between individual national registries [16]. The inclusion or exclusion of in situ bladder cancer (INSB) into the category of malignant neoplasms represents a difference with the greatest impact on the results of any analysis [17]. The prognosis of a patient with INSB is much more favorable than that of a patient with invasive MTB. The time trend analysis is, therefore, likely to yield different results for data according to the inclusion of INSB. Subsequent primary neoplasms (SPN) constitute another category of tumors representing a potential problem for the comparability. Their incidence is increasing due to the improvements in cancer care. Their inclusion in or exclusion from the analysis can therefore also influence the resulting epidemiological characteristics. All these pose a question to what extent the observed trend changes result from the improving quality of care or differences in the exposure to risk factors and to what extent they are just a result of classification/coding changes.

The presented study aimed to perform a complex evaluation of time trends of incidence, mortality, and survival of BN based on the national database of the Czech National Cancer Registry in the period of 1977-2017. A detailed evaluation of both MTB and INSB, and an analysis of $\mathrm{BN}$ occurring as SPN were performed.

\section{Materials and methods}

\section{Data sources}

The database of the Czech National Cancer Registry (CNCR) [18] constituted the principal data source for this study. The CNCR database provides records of all neoplasms in the Czech population since 1976. BN were identified in accordance with the $10^{\text {th }}$ Edition of the International Classification of Diseases (ICD-10) based on the C67 code for MTB and D09.0 for INSB [19]. All BN recorded in the CNCR between 1977 and 2017 were included in the analysis. In total, 76,505 BN entered the analysis, of which 69,826 were MTB and 6,679 were INSB. Based on the internationally standardized rules for multiple primary neoplasm coding issued by the International Association for Cancer Research (IARC) [20], the identified $\mathrm{BN}$ were classified as either first primary neoplasms (FPN) or SPN. Only BN that were preceded by other malignancy than that of the bladder were denoted as SPN to prevent the difficult decision making whether the tumor is an SPN on the same site or whether it is a recurrent old malignancy. We also utilized data on the demographic structure of the Czech Republic provided by the Czech Statistical Office [21].

\section{Statistical analysis}

Age-standardized incidence and mortality were calculated using the direct standardization method based on the 
Tab. 1. Basic epidemiological characteristics of bladder neoplasms.

\begin{tabular}{|c|c|c|c|}
\hline Incidence & MTB (C67) & INSB (D090) & Total \\
\hline absolute number of cases (2017) & 2,155 & 880 & 3,035 \\
\hline number of cases per 100,000 population (2017) & 20.4 & 8.3 & 28.7 \\
\hline age-standardized rate ASRe (2017) & 21.2 & 8.5 & 29.7 \\
\hline male/female ratioa (2013-2017) & 2.9 & 2.8 & 2.9 \\
\hline proportion of all MT (2013-2017) & $2.5 \%$ & - & - \\
\hline proportion of MT except for C44 (2013-2017) & $3.7 \%$ & - & - \\
\hline age at diagnosis ${ }^{b}(2013-2017)$ & $71(64-78)$ & $70(64-76)$ & $71(64-78)$ \\
\hline lifetime risk of developing neoplasm (2013-2017) & $1.7 \%$ & $0.6 \%$ & $2.3 \%$ \\
\hline European ranking ${ }^{c}$ & 18.-19. & - & - \\
\hline worldwide ranking ${ }^{c}$ & 23.-25. & - & - \\
\hline
\end{tabular}

\section{Mortality}

absolute number of cases (2017)

number of cases per 100,000 population (2017)

874

8.3

27

901

age-standardized rate ASRe (2017)

9.1

0.3

8.5

proportion of all MT-caused deaths (2013-2017)

$3.1 \%$

proportion of all MT-caused deaths without C44 (2013-2017)

$3.1 \%$

age at death ${ }^{\mathrm{b}}(2013-2017)$

lifetime risk of the neoplasm-caused death (2013-2017)

$76(69-83)$

$0.8 \%$

0.3

9.4

European ranking ${ }^{c}$

worldwide ranking ${ }^{c}$

18.-19.

36.-39.

\section{Prevalence}

absolute number of cases (2017)

number of cases per 100,000 population (2017)

age of surviving patients ${ }^{\mathrm{b}}$ (2017)

\section{4,953}

46.8

72 (65-78)

\section{2,874}

216.0

73 (66-79)

${ }^{a}$ ratio calculated from the incidence per 100,000 population of men over women

${ }^{\mathrm{b}}$ median age (25.-75. percentile)

'Data source: GLOBOCAN 2018 (comparison based on the number of C67 cases per 100,000 of the age-standardized world population. Country ranking is according to decreasing incidence/mortality (first place taken by the country with the highest incidence/mortality).

ASRe - number of cases per 100,000 population, age-standardized to the 2013 European age standard, INSB - in situ bladder cancer, MT - malignant tumor, MTB - malignant tumor of the bladder

European standard population issued by Eurostat in 2013 [22]. The localized stage was defined as clinical stage I, regional as clinical stages II+III and distant stage as the clinical stage IV. The comparison of the first (1978-1987) and last period (2008-2017) was performed using the $\mathrm{N}-1$ chi-squared test [23].

The analysis of the time trends of incidence and mortality was performed using a joinpoint regression model, in which the dependent variable (incidence or mortality) is described by a piecewise linear continuous function [24]. The grid search method was used for selecting the optimal joinpoint model. The best model was selected through permutation testing with 4,500 random permutations. To quantify the observed trends, the annual percentage change (APC) was estimated for individual identified segments and, in addition, an average annual percentage change (AAPC) for the period of the last 10 years (20082017) was estimated $[25,26]$. Point estimates of APC and AAPC, together with respective $95 \%$ confidence intervals, were used for characterizing the trends.

Patient survival time was defined as the period from diagnosis until the death of 
Tab. 2. Temporal development of basic characteristics of bladder neoplasms.

\begin{tabular}{|c|c|c|c|c|c|}
\hline \multirow[b]{2}{*}{ Gender } & \multicolumn{4}{|c|}{ Period of diagnosis } & \multirow[t]{2}{*}{ P-value } \\
\hline & 1978-1987 & 1988-1997 & 1998-2007 & 2008-2017 & \\
\hline men & $8,212(78.4 \%)$ & $11,711(74.8 \%)$ & $15,918(73.1 \%)$ & $20,412(73.6 \%)$ & $<0.001$ \\
\hline women & 2,269 (21.6\%) & $3,940(25.2 \%)$ & $5,872(26.9 \%)$ & 7,309 (26.4\%) & $<0.001$ \\
\hline Age at diagnosis & 1978-1987 & 1988-1997 & 1998-2007 & 2008-2017 & \\
\hline$\leq 64$ & 3,811 (36.4\%) & $5,553(35.5 \%)$ & 7,543 (34.6\%) & 7,929 (28.6\%) & $<0.001$ \\
\hline $65-74$ & 3,736 (35.6\%) & $5,794(37.0 \%)$ & $7,444(34.2 \%)$ & $10,118(36.5 \%)$ & 0.121 \\
\hline$\geq 75$ & $2,934(28.0 \%)$ & $4,304(27.5 \%)$ & $6,803(31.2 \%)$ & 9,674 (34.9\%) & $<0.001$ \\
\hline Clinical staging ${ }^{b}$ & 1982-1990 & 1991-1999 & 2000-2008 & 2009-2017 & \\
\hline in situ & $112(2.8 \%)$ & 207 (2.3\%) & 780 (4.7\%) & $5,550(23.3 \%)$ & $<0.001$ \\
\hline localized & $1,162(29.5 \%)$ & $4,211(46.8 \%)$ & $10,065(60.4 \%)$ & $11,100(46.7 \%)$ & $<0.001$ \\
\hline regional & 1,894 (48.1\%) & 3,491 (38.8\%) & 4,315 (25.9\%) & 4,818 (20.3\%) & $<0.001$ \\
\hline distant & 770 (19.6\%) & $1,094(12.2 \%)$ & $1,506(9.0 \%)$ & $2,322(9.8 \%)$ & $<0.001$ \\
\hline First/subsequent primary neoplasms & 1978-1987 & 1988-1997 & 1998-2007 & 2008-2017 & \\
\hline FPN & $9,962(95.0 \%)$ & $14,201(90.7 \%)$ & $18,450(84.7 \%)$ & $21,217(76.5 \%)$ & $<0.001$ \\
\hline SPN & $519(5.0 \%)$ & $1,450(9.3 \%)$ & $3,340(15.3 \%)$ & $6,504(23.5 \%)$ & $<0.001$ \\
\hline Smoking historyc & 2000-2004 & 2005-2009 & 2010-2013 & 2014-2017 & \\
\hline non-smokers & $2,970(48.7 \%)$ & $3,179(45.6 \%)$ & $2,931(44.3 \%)$ & $3,136(41.4 \%)$ & $<0.001$ \\
\hline former smokers & $1,174(19.3 \%)$ & $1,534(22.0 \%)$ & $1,470(22.2 \%)$ & $1,859(24.6 \%)$ & $<0.001$ \\
\hline current smokers & $1,953(32.0 \%)$ & $2,253(32.3 \%)$ & $2,221(33.5 \%)$ & $2,576(34.0 \%)$ & 0.014 \\
\hline \multicolumn{6}{|c|}{$\begin{array}{l}\text { b classification according to clinical stages only available since 1982; only cases with known staging included in the analysis } \\
\text { c smoking history is recorded only since } 2000 \text { in CNCR data; only cases with known smoking history included in the analysis } \\
\text { FPN - first primary neoplasms; SPN - subsequent primary neoplasms }\end{array}$} \\
\hline
\end{tabular}

the patient or until the end of the observation period (31. 12. 2018). For evaluation of the survival, relative survival was defined as the ratio of overall survival over the expected survival [27]. Survival analysis was performed only for the period from 1990 onwards. The reason is that until 1990, the use of many treatment methods, in particular cytostatics, was limited due to the difficulties of their import into the communist country. Beginning the analysis in 1990, we have set the initial conditions to reflect the new socio-economic realities after the transition to democracy in late 1989. Neoplasms identified post mortem (i.e., those based on death certificates or autopsy findings only) were also excluded from the analysis. Point estimates of survival were supplemented with $95 \%$ confidence intervals. Cohort analysis was used for case selection, except for the most recent period of 2013-2017, in which the patients were selected using the period method [28]. Relative survival values were age-standardized for the period of 2013-2017 [29].

Cox proportional hazards model was used to determine survival predictors in patients with MTB in 2003-2017. Fiveyear survival was used as a primary endpoint, observations with $\geq 5$ years of follow-up were censored at 5 years. $\mathrm{Pa}$ tients with unknown clinical staging or smoking history were excluded from the analysis. For each variable, a separate univariate regression model was prepared and subsequently, a resulting multivariate regression model was created, in which the final variables were selected through the backward elimination method. The Cox regression model was then used to determine the hazard ratio and $95 \%$ confidence interval for individual variables.

The analysis was performed using the software R, version 3.5.3 [30], the IBM SPSS Statistics version 25 [31], the StatalC version 15.1 [32] and the Joinpoint Regression Program, version 4.7.0.0 [33].

\section{Results}

\section{Epidemiological overview}

The current epidemiological situation of BN is summarized in Tab. 1. In 2017, MTB were the $8^{\text {th }}$ most frequently diagnosed neoplasm in the Czech Republic (excepting non-melanoma skin cancer, (44) and, at the same time, the $10^{\text {th }}$ most common cause of death among oncological diagnoses. The incidence in men was significantly higher than in 
women. The lifetime risk of developing MTB equaled to $3.6 \%$ in men and $1.2 \%$ in women for the period 2013-2017. The lifetime risk of MTB-related death showed a similar trend and reached $1.2 \%$ in men and $0.4 \%$ in women.

Temporal development of epidemiological characteristics Over the analyzed period, the relative representation of women among newly diagnosed cases significantly increased (a 4.8\% difference between the first and last studied period) (Tab. 2). The mean age at diagnosis shifted upwards over time. Comparing the first and last analyzed decades, a statistically significantly lower proportion of patients belonged to the age category $\leq 64$ years (a decrease by $7.8 \%$ ) and the proportion of patients in the highest age category of $\geq 75$ years significantly increased (an increase by 6.9\%). Changes were also observed in a stage at diagnosis. Over time, a major drop in the number of cases classified as unknown stage was observed (from $62.6 \%$ in the first period with recorded staging, i.e. in the $1982-1990$ period, to $5.9 \%$ in the 2009-2017 period). Among the known stages, a significant increase in the proportion of INSB and localized MTB was observed, along with a decrease in the representation of regional and distant stages. Over time, the relative number of SPN climbed steeply (by $18.5 \%$ when comparing the first and last studied periods). Since 2000 , the smoking history of patients is also available in the CNCR. Comparing the first and last periods, the proportion of current and former smokers significantly increased among patients with known smoking history. Correspondingly, the share of non-smokers significantly decreased.

\section{Time trends of incidence and mortality}

The joinpoint regression analysis revealed an average annual increase in the age-standardized incidence of MTB in the period of $1977-1996$ by $4.1 \%(P<0.001)$. In the following period (1996-2004), the growth slowed down (APC increased by $1.6 \% ; P=0.003)$. After 2004, the trend was reversed and a statistically significant de- crease by $1.9 \%$ was observed $(P<0.001)$ (Fig. 1). The trends of incidence did not differ significantly between genders, and the increase until 2004 was followed by an annual decline by about $2 \%$ for both men and women. A slight difference was observed only for the initial period of 1977-2004 (AAPC increased by $2.9 \%$ in men, $\mathrm{P}<0.001$, and by $4.6 \%$ in women, $P<0.001)$. The analysis of age associations showed that the observed decrease in incidence was less pronounced in the older age groups (Fig. 1). In addition, the statistically significant decrease in incidence was observed significantly later in the $\geq 75$ age category than in the younger age categories for both men and women. Major differences were shown in the incidence trends for individual stages of the disease at diagnosis. There was a significant increase in the diagnoses of the localized stage until 2004; this was followed by stabilization and since 2010, a statistically significant annual decrease by $4.1 \%$ has been observed $(P<0.001)$. The incidence of the regional stage reached a plateau after the initial growth. The incidence of the distant stage grew until 2009, being followed by a trend of decrease, which was, however, not statistically significant $(\mathrm{P}=0.052)$.

In the period of the statistically significant decline in the incidence of MTB, a significant increase in the number of cases diagnosed with INSB can be observed (Fig. 1). The joinpoint model reveals a significant trend change in 2002 (95\% Cl: 1999-2005), after which the number of cases steeply increases. The trend was not significantly different between genders (in 2008-2017, AAPC increased by $16.6 \%$ in men, $P<0.001$, and by $16.2 \%$ in women, $P<0.001$ ). From the perspective of the age groups, a significant increase can also be observed after 2002, with greater growth occurring in the older age categories.

Until 1998, the age-standardized mortality of MTB grew by $1.9 \%$ annually $(P<0.001)$; after that year, the trend was reversed and a significant decrease in mortality by $1.4 \%$ annually $(P<0.001$ ) was observed. The decrease was slightly more pronounced in men (AAPC in the 2008-2017 period decreased by $1.9 \%$ in men, $\mathrm{P}<0.001$, and by $1.2 \%$ in women, $P<0.001)$. Comparing the age categories, the decline in age-standardized mortality is (similar to incidence) greater in the younger age categories (Fig. 1). Similarly, the trends of mortality according to clinical staging are in accordance with the trends of incidence; the only exception is the localized stage where (unlike for incidence) no statistically significant decrease in mortality can be observed in the recent period.

\section{Subsequent primary neoplasms of the bladder}

Over the last years, an increase in the number of patients with subsequent primary neoplasms has been observed. In the most recent analyzed period (20132017), almost one in four (24.2\%) MTB and almost one in three (30.8\%) INSB were identified as SPN.

The joinpoint regression analysis revealed significant differences in the trends of incidence and mortality for neoplasms diagnosed as FPN/SPN (Fig. 1). While the age standardized incidence of the first primary MTB declines by $2.8 \%$ annually $(P<0.001)$ since 2005 , the increase in the incidence of SPN remained statistically significant ( $P=0.006)$, although it is obvious that the rate of the increase was slowing. A similar development was observed in the case of agestandardized mortality of patients with MTB. While the mortality due to FPN has been decreasing ever since 1999, only a slight stabilization after 2006 was observed in case of SPN. The incidence of INSB as the first, as well as subsequent, primary neoplasms climbs steeply since 2004; this trend was, however, much stronger in the case of SPN.

\section{Survival}

The five-year relative survival of patients with MTB in the most recent period of $2013-2017$ was $62.3 \%(95 \% \mathrm{Cl}$ 61.1-63.5\%). Considering the MTB together with INSB, survival in the same period was $69.1 \%$ (95\% Cl 68.0-70.2\%). Fig. 2 shows the development of the survival of patients with $\mathrm{BN}$ for six time periods since 1990 . The graph indicates that in the first three periods (until 2002), a marked improvement in survival of 


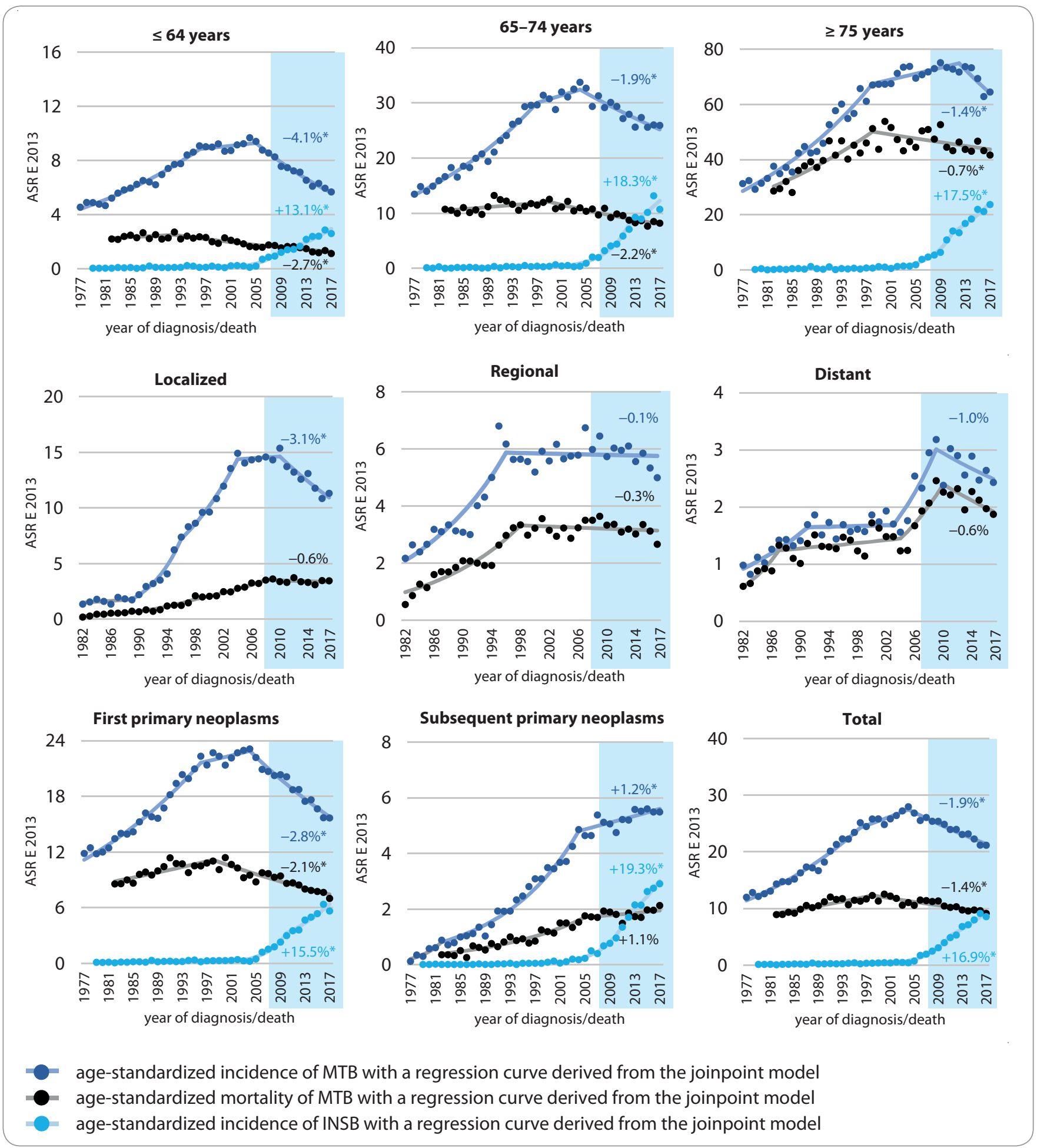

Fig. 1. Trends of the incidence and mortality of bladder neoplasms according to the age at diagnosis, clinical staging and order of tumor occurrence.

$\%$ - average annual percentage change in 2008-2017 derived using joinpoint regression, ${ }^{*}$ - statistically significant average annual percentage change (5\% level of significance), ASR E 2013 - age-standardized rate (European standard population), MTB - malignant tumor of the bladder, INSB - in situ bladder cancer

MTB was observed, which was followed by stagnation in the next period (20032007) and decreased relative survival in the last two periods (2008-2017). Where INSB is concerned, the survival keeps steadily growing with the exception of the last period showing stagnation. Combining MTB and INSB into a single cohort, we can observe a steady increase 
Five-year relative survival with the $95 \%$ confidence interval

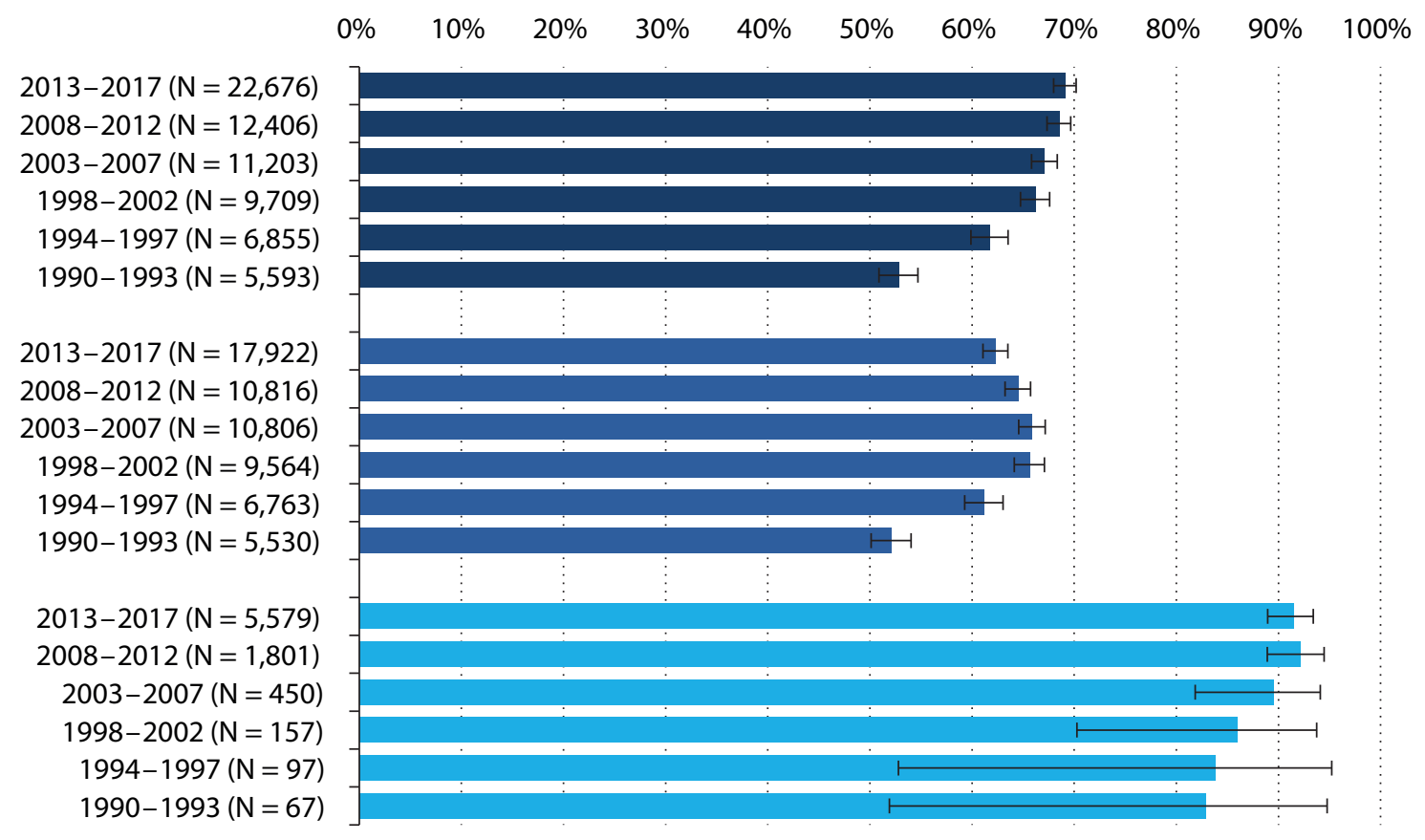

five-year survival of patients with MTB and INSB

five-year survival of patients with MTB

five-year survival of patients with INSB

$95 \%$ confidence interval

MTB - malignant tumor of the bladder, INSB - in situ bladder cancer

Fig. 2. The temporal development of the five-year relative survival in patients with bladder neoplasms.

in the proportion of surviving patients over the entire period. The same trends were observed for both genders. In the recent period of 2013-2017, the five-year survival was almost identical for both men and women; the survival rate was $62.5 \%$ (95\% Cl 61.0-63.9\%) in men with MTB, and $62.2 \%(95 \% \mathrm{Cl} 59.9-64.3 \%)$ in women. When including INSB into the analysis, survival increased to $69.2 \%$ (95\% Cl 67.9- 70.6\%) for men and to $69.0 \%$ (95\% Cl 67.0-71.0\%) for women.

In the univariate Cox models, all analyzed variables were shown to be statistically significant predictors of the five-year survival of patients with MTB in 2003-2017 (Tab. 3). The predictors of lower survival were: male gender, later year of diagnosis, higher age at diagnosis, more advanced clinical stage, subsequent primary tumor, and non-smoking status. Regarding smoking history, the hazard ratio of mortality was signif- icantly lower in current smokers compared to non-smokers (HR 0.95; 95\% $\mathrm{Cl}$ : 0.90-0.99). On the other hand, the median age of diagnosis in smokers (65 years) was significantly lower than in non-smokers (73 years). In contrast, after adjustment for age, the risk was approximately $40 \%$ higher in current smokers than in non-smokers (HR 1.36; $95 \% \mathrm{Cl}$ 1.30-1.43).

In the final multivariate Cox model, statistically significant predictors of fiveyear survival comprised the age at diagnosis, order of the neoplasm (first/subsequent), clinical stage at diagnosis, and smoking history (Tab. 3). Neither the gender nor the date of diagnosis led to significant improvement of the model and were removed from it. After taking the influence of other variables into account, therefore, the multivariate model showed that a later year of diagnosis was not associated with worse survival.

\section{Discussion}

A significant decrease in the incidence of MTB after 2004 was observed. Recent studies reported a similar trend in many other countries $[2,4,11,13,15,34]$. This development is caused predominantly by improved detection of BN already at the stage of INSB and by changes in the classification of $\mathrm{BN}$. In the past, invasive and non-invasive $\mathrm{BN}$ were recorded as a single diagnostic group. By the end of the 1990s, new European and international guidelines were issued, recommending to single out non-invasive carcinomas and their new classification as INSB or carcinomas of uncertain behavior [11]. This resulted in a drop in the number of diagnosed MTB. This is in accordance with the results of INSB incidence in our study, revealing that the incidence of INSB climbs steeply simultaneously with the drop in the MT incidence. The data of the Surveillance Epidemiology and End 
Tab. 3. Hazard ratios for five-year survival derived from the Cox regression models for - malignant tumors of the bladder in 2003-2017 ( $=18,708)$.

\begin{tabular}{|c|c|c|c|c|}
\hline \multirow[b]{3}{*}{ Gender } & \multicolumn{2}{|c|}{ Univariate } & \multicolumn{2}{|c|}{ Multivariate $^{a}$} \\
\hline & HR $(95 \% \mathrm{Cl})$ & P-value & HR (95\% CI) & P-value \\
\hline & & & & \\
\hline men $(\mathrm{N}=13,860)$ & 1.00 & & NS & \\
\hline women $(\mathrm{N}=4,848)$ & $0.94(0.90-0.99)$ & 0.020 & & \\
\hline \multicolumn{5}{|l|}{ Age at diagnosis } \\
\hline$\leq 64(\mathrm{~N}=6,198)$ & 1.00 & & 1.00 & \\
\hline $65-74(N=6,658)$ & $1.61(1.51-1.70)$ & $<0.001$ & $1.61(1.52-1.71)$ & $<0.001$ \\
\hline$\geq 75(\mathrm{~N}=5,852)$ & $2.85(2.70-3.01)$ & $<0.001$ & $2.98(2.81-3.17)$ & $<0.001$ \\
\hline \multicolumn{5}{|l|}{ Year at diagnosis } \\
\hline 2003-2007 (N = 5,708) & 1.00 & & NS & \\
\hline $2008-2012(N=6,551)$ & $1.13(1.07-1.19)$ & $<0.001$ & & \\
\hline 2013-2017 (N = 6,449) & $1.28(1.21-1.35)$ & $<0.001$ & & \\
\hline \multicolumn{5}{|l|}{ Clinical stage } \\
\hline localized $(\mathrm{N}=11,502)$ & 1.00 & & 1.00 & \\
\hline regional $(\mathrm{N}=5,000)$ & $3.11(2.96-3.27)$ & $<0.001$ & $3.01(2.86-3.16)$ & $<0.001$ \\
\hline distant $(\mathrm{N}=2,206)$ & $8.72(8.23-9.24)$ & $<0.001$ & $9.23(8.71-9.79)$ & $<0.001$ \\
\hline \multicolumn{5}{|l|}{ First/subsequent primary neoplasm } \\
\hline first primary neoplasm $(\mathrm{N}=14,974)$ & 1.00 & & 1.00 & \\
\hline subsequent primary neoplasm $(\mathrm{N}=3,734)$ & $1.45(1.38-1.53)$ & $<0.001$ & $1.28(1.21-1.35)$ & $<0.001$ \\
\hline \multicolumn{5}{|l|}{ Smoking history } \\
\hline non-smokers $(\mathrm{N}=8,260)$ & 1.00 & & 1.00 & \\
\hline former smokers $(\mathrm{N}=4,205)$ & $1.13(1.07-1.20)$ & $<0.001$ & $1.09(1.03-1.15)$ & 0.002 \\
\hline current smokers $(\mathrm{N}=6,243)$ & $0.95(0.90-0.99)$ & 0.035 & $1.17(1.11-1.23)$ & $<0.001$ \\
\hline
\end{tabular}

a final multivariate Cox proportional hazards model; selection of the final variables performed using the backward elimination method

$\mathrm{Cl}$ - confidence interval, HR - hazard ratio, NS - not significant

Results (SEER) in the USA consider both MTB and INSB as one diagnostic class to facilitate statistical evaluation (particularly to prevent changes in the interpretation of time trends due to classification changes) $[17,35]$. This approach leads to a relatively high reported incidence of MTB with a stable trend [35]. Over the last years, however, even SEER data indicate a slight decrease (AAPC dropped by $1.0 \%$ in 2008-2017; $P<0.05)$.

The mortality associated with MTB significantly decreased in the Czech Republic after 1998. As non-invasive neoplasms are usually associated with good prognosis, it is unlikely that the above- mentioned changes in classification would have influenced the trends in mortality. Antoni et al [11] proposed that mortality is a more useful indicator for measuring and comparing the temporal or geographical changes in the general progress and treatment improvement of $\mathrm{BN}$ at the population level than incidence. In most countries, a statistically significant decrease in mortality was observed regardless of whether only MTB or combined MTB and INSB were considered in the studies $[2,4,11,12,34-36]$.

The declining incidence and mortality of MTB are also associated with reduced exposure to risk factors, especially smok- ing and occupational exposure to carcinogens [4,37-41]. Approx. 50\% of cases are reported to be associated with smoking of tobacco products; the decreasing prevalence of smoking could have, therefore, played an important role [42-44]. In the Czech Republic, a drop in the smoking prevalence from $30.7 \%$ to $25.2 \%$ was recorded between 2004 and 2017 (AAPC decreased by $0.8 \% ; P=0.112$ ). Similarly, a decrease in smoking prevalence has been observed in other countries reporting a decrease in the incidence and mortality of MTB [45-47].

The decrease in the incidence and mortality of MTB was weaker in older 
age groups. Contrarily, a higher increase in the incidence of INSB was observed in the older age categories. These results are also consistent with previously published studies [15,34]. As far as staging is concerned, the greatest decrease in incidence and mortality was observed for localized and distant stages. These changes reflect the progress in diagnostic and therapeutic methods and are also associated with an increased capture of neoplasms in the INSB stages, which prevents their development into later (invasive) stages. Similar results were also published in other studies $[13,14]$.

Studies evaluating the global trends of incidence and mortality in association with gender indicate that the trends are in many countries stable or decreasing in men while growing in women $[2,11,13]$. This fact was not confirmed in our study. The decreasing trend in the recent period was revealed both for men and women, which can be related to the similar decrease in the prevalence of smoking for both genders.

Neoplasms diagnosed as SPN are a serious present-day clinical problem. In patients who had gone through an oncological disease in the past, the risk of developing a new primary neoplasm is significantly higher than in the general population. This is caused by multiple factors, including genetic predispositions, cancer treatment of the previous neoplasm (in particular, chemotherapy and radiotherapy), lifestyle, environmental exposure, etc. [48]. In SPN, it is also necessary to mention different definitions and classification rules across registries. A study evaluating the impact of the use of various definitions identified significant differences in the numbers of neoplasms considered as FPN or SPN following the use of different definitions [49]. Two definitions that are currently most widely used are those set by SEER and IACR, with the latter having been used in our study $[20,50]$. The use of different rules can (similar to the inclusion or exclusion of INSB), therefore, to a great degree influence the overall statistics and trends of $\mathrm{BN}$ as our results indicate significant differences in the trends for FPN and SPN.
The five-year relative survival of MTB was $62.3 \%$ in the recent period of 2013 2017 , which is slightly higher than reported in studies on other populations [15,34,51,52]. When including both INSB and MTB into the analysis, the survival grew to $69.1 \%$, which is, on the contrary, a slightly lower value than reported elsewhere $[13,15,35]$. The study EUROCARE-5, which provides an international comparison of survival in all European countries, reported the mean survival of patients with BN (both invasive and noninvasive) in Europe to be $68.6 \%$ and the value for the Czech Republic was slightly better than the average, namely $70.8 \%$. All these differences are, nevertheless, small and can be caused by differences in the calculation methods and analyzed periods. Unlike in other oncological diagnoses, significantly better survival rates of $\mathrm{BN}$ are reported for men than for women $[13,15,34,35,51]$. Reasons for this are extensively discussed in the available literature; the most widely accepted opinion is later diagnosis in women, associated with more advanced stages at diagnosis $[13,15,53,54]$. In our studies, no significant difference in survival between genders was revealed, the survival of men and women in the recent period was practically identical. This can be caused by the fact that in the Czech Republic, we have not found any significant difference in clinical stages at diagnosis between genders.

Several studies have reported a stagnation or decrease in survival rates of MTB in the recent period $[15,34,51]$. The same trend has been observed in our study; we observed a decreasing tendency since 2003. This, to a great extent, results from the aforementioned increased INSB detection and change in neoplasm classification. The prognosis of INSB is much better than that of MTB and their exclusion from the analysis of MTB necessarily leads to worse survival rates. In our analysis, we have also shown that the apparent unfavorable development of survival in patients with MTB in the recent period was eliminated after taking the other considered variables into account. The results of the analysis show that the decrease in the survival of MTB in the recent period is caused by the increasing age at diagnosis, increasing proportion of smokers among newly diagnosed patients, and, last but not least, by the growing proportion of SPN. When analyzing the combined MTB+INSB patient group, the survival rates keep steadily growing over the entire period. An interesting fact is that the combined survival rate is growing even in the periods 2008-2012 and 2013-2017, despite a slight decrease in survival of both MTB and INSB separately. This is caused by the significantly increasing proportion of INSB among newly diagnosed neoplasms over time. While in 2008-2012, the proportion of INSB among diagnosed BN was $14 \%$, it steeply climbed to $27 \%$ in $2013-2017$. The trend of survival improvement was reported in other studies analyzing the combined MTB+INSB population as well $[13,15]$. On the other hand, according to the latest SEER report, a trend of stagnation or even a slight decrease in survival is reported in the last years despite analyzing a combined MTB+INSB population, which can be associated with the aforementioned factors, in particular with the growing proportion of SPN [35].

\section{Conclusions}

This study summarizes the long-term time trends of incidence, mortality, and survival of bladder neoplasms in the Czech Republic. The results of the analysis showed a significant effect of in situ bladder cancer on the interpretation of the time trends of epidemiological characteristics, in particular incidence and survival. At present, the international comparability of epidemiological characteristics for BN is limited to a great degree due to classification and coding differences used in individual national registries and their unification would be beneficial for the validity of future studies. The presented analysis also revealed significant differences in trends for tumors classified as FPN or SPN. To the best of our knowledge, no study published so far investigated the trends for BN in association with their diagnosis as first or subsequent primary tumors. In view of the fact that SPN have formed more than a quarter of all diagnosed $B N$ 
recently and their share can be expected to keep growing in the future, the evaluation of trends from this perspective is highly insightful and this topic calls for further studies.

\section{Acknowledgements}

We would like to thank all experts participating in the collection and administration of data for the National Oncological Registry without whom this study would not be possible. This study was supported by the INTENT and iPAAC research programs.

\section{References}

1. Bray F, Ferlay J, Soerjomataram I et al. Global cancer statistics 2018: GLOBOCAN estimates of incidence and mortality worldwide for 36 cancers in 185 countries. CA Cancer J Clin 2018; 68(6): 394-424. doi: 10.3322/caac.21 492.

2. Wong MCS, Fung FDH, Leung C et al. The global epidemiology of bladder cancer: a joinpoint regression analysis of its incidence and mortality trends and projection. Sc Rep 2018; 8(1): 1129. doi: 10.1038/s41598-018-19199-z. 3. Mohammadian M, Safari A, Allah Bakeshei K et al. Recent patterns of bladder cancer incidence and mortality: a global overview. World J Cancer Res 2020; 7: e1464. doi: 10.32113/wcrj_20201_1464.

4. Chavan S, Bray F, Lortet-Tieulent J et al. Internationa variations in bladder cancer incidence and mortality. Eu Urol 2014; 66(1): 59-73. doi: 10.1016/j.eururo.2013.10.001. 5. Burger M, Catto JWF, Dalbagni G et al. Epidemiology and risk factors of urothelial bladder cancer. Eur Urol 2013; 63(2): 234-241. doi: 10.1016/j.eururo.2012.07.033. 6. Colombel M, Soloway M, Akaza $\mathrm{H}$ et al. Epidemiology، staging, grading, and risk stratification of bladder cancer. Eur Urol 2008; 7(10): 618-626.

7. Young C, Rushton L, British Occupational Cancer Burden Study Group. Occupational cancer in Britain. Skin cancer. Br J Cancer 2012; 107 (Suppl 1): S71-S75. doi: 10.1038/bjc.2012.120.

8. Farzaneh F, Mehrparvar AH, Lotfi MH. Occupations and the risk of bladder cancer in yazd province: a case-contro study, Int J Occup Environ Med 2017; 8(4): 191-198. doi: 10.15171/ijoem.2017.1085

9. Ghadimi T, Gheitasi B, Nili S et al. Occupation, smoking, opium, and bladder cancer: a case-control study. South Asian J Cancer 2015; 4(3): 111-114. doi: 10.4103/2278330X.173174.

10. Sondik E. Measurement of progress against cancer Extramural Committee to Assess Measures of Progress Against Cancer. J Natl Cancer Inst 1990: 82(10): 825-835. 11. Antoni S, Ferlay J, Soerjomataram I et al. Bladder cancer incidence and mortality: a global overview and re cent trends. Eur Urol 2017; 71(1): 96-108. doi: 10.1016/j. eururo.2016.06.010

12. Liu X, Jiang J Yu C et al Secular trends in incidence and mortality of bladder cancer in China, 1990-2017: a joinpoint and age-period-cohort analysis. Cancer Epidemiol 2019: 61:95-103 doi: 10.1016/j.canep.2019.05.011. 13. Andreassen BK, Aagnes B, Gislefoss R et al. Incidence and survival of urothelial carcinoma of the urinary bladder in Norway 1981-2014. BMC Cancer 2016; 16(1): 799. doi: 10.1186/s12885-016-2832-x.

14. Abdollah F, Gandaglia G, Thuret R et al. Incidence, survival and mortality rates of stage-specific bladder cancer in United States: a trend analysis. Cancer Epidemiol 2013; 37(3): 219-225. doi: 10.1016/j.canep.2013.02.002.
15. Luke C, Tracey E, Stapleton A et al. Exploring contrary trends in bladder cancer incidence, mortality and survival: implications for research and cancer control. Intern Med J 2010; 40(5): 357-363. doi: 10.1111/j.1445 5994.2009.01980.x.

16. Crow P, Ritchie AWS. National and international variation in the registration of bladder cancer. BJU Int 2003 92(6): 563-566. doi: 10.1046/j.1464-410x.2003.04421 x 17. Hankey BF, Edwards BK, Ries LA et al. Problems in cancer surveillance: delineating in situ and invasive bladder cancer. J Natl Cancer Inst 1991; 83(6): 384-385. do: 10.1093/jnci/83.6.384

18. Institute of Health Information and Statistics of the Czech Republic. Czech National Cancer Registry. [online]. Available from: http://www.uzis.cz/registry-nzis/nor. 19. World Health Organization. International statistical classification of diseases and related health problems. [online]. Available from: https://www.who. int/standards/classifications/classification-of-diseases. 20. IACR \& ENCR. International rules for multiple primary cancers (ICD-0 third edition). [online]. Available from: http://www.iacr.com.fr/images/doc/MPrules_july20 04.pdf.

21. Czech statistical office. Statistical Yearbook of the Czech Republic - 2017. [online]. Available from https://www.czso.cz/csu/czso/statistical-yearbook-ofthe-czech-republic.

22. Eurostat Methodologies and Working Papers. Revision of the European Standard Population: report of Eurostat's task force: 2013 edition. [online]. Available from: https://ec. europa.eu/eurostat/documents/3859598/5926869/KS RA-13-028-EN.PDF/e713fa79-1add-44e8-b23d-5e8faO $9 \mathrm{~b} 3 \mathrm{f} 8 \mathrm{f}$

23. Campbell I. Chi-squared and Fisher-Irwin tests of two by-two tables with small sample recommendations. Stat Med 2007; 26(19): 3661-3675. doi: 10.1002/sim.2832. 24. Kim HJ, Fay MP, Feuer EJ et al. Permutation tests for joinpoint regression with applications to cancer rates. Stat Med 2000; 19(3): 335-351. doi: 10.1002/(sici)1097 0258(20000215) 19:3<335::aid-sim336>3.0.co:2-z.

25. Kleinbaum DG, Kupper LL, Muller KE et al. Applied regression analysis and other multivariable methods. North Scituate, Mass: Duxbury Press 1988

26. Clegg LX, Hankey BF, Tiwari R et al. Estimating averag annual per cent change in trend analysis. Stat Med 2009; 28(29): 3670-3682 doi: 10.1002/sim.3733.

27. Ederer F, Axtell LM, Cutler SJ. The relative survival rate: a statistical methodology. Natl Cancer Inst Monogr 1961; 6: 101-121.

28. Brenner $\mathrm{H}$, Gefeller O. An alternative approach to monitoring cancer patient survival. Cancer 1996; 78(9): 2004-2010.

29. Corazziari I, Quinn M, Capocaccia R. Standard cancer patient population for age standardising survival ratios. Eur J Cancer 2004; 40(15): 2307-2316. doi: 10.1016/j. ejca.2004.07.002

30. R Core Team. The R project for statistical computing. [online]. Available from: https://www.R-project.org/. 31. IBM Corp. Released 2017. IBM SPSS Statistics for Windows, Version 25.0. Armonk, NY: IBM Corp.

32. StataCorp (2017) Stata statistical software: release 15. college station, TX: StataCorp LLC. [online]. Available from: https://www.scirp.org/(S(i43dyn45tee xjx455qlt3d2q))/reference/ReferencesPapers.aspx? ReferencelD $=2629339$.

33. National Cancer Institute. Surveillance research program. [online]. Available from: https://surveillance.cancer.gov/.

34. Cancer research UK. [online]. Available from: https://www.cancerresearchuk.org/.
35. National Cancer Institute. SEER cancer statistics review 1975-2017. [online]. Available from: https://seer.cancer. gov/archive/csr/1975_2017/.

36. Malmström P-U, Gårdmark T, Sherif A et al. Incidence, survival and mortality trends of bladder cancer in Sweden 1997-2016. Scand J Urol 2019; 53(4): 193-199. doi: 10.1080/21681805.2019.1632380.

37. Kaufman DS, Shipley WU, Feldman AS. Bladder cancer. Lancet 2009; 374(9685): 239-249. doi: 10.1016/S0140-6736(09)60491-8.

38. Gandini $\mathrm{S}$, Botteri E, lodice $S$ et al. Tobacco smoking and cancer: a meta-analysis. Int J Cancer 2008; 122(1): 155-164. doi: 10.1002/ijc.23033.

39. Rushton L, Hutchings SJ, Fortunato L et al. Occupational cancer burden in Great Britain. Br J Cancer 2012; 107 (Suppl 1): S3-S7. doi: 10.1038/bjc.2012.112.

40. Steinmaus CM, Ferreccio C, Romo JA et al. Drinking water arsenic in Northern Chile: high cancer risks 40 years after exposure cessation. Cancer Epidemiol Biomarkers Prev 2013: 22(4): 623-630. doi: 10.1158/1055-9965.EPI-12-1190. 41. Ferlay J, Randi G, Bosetti C et al. Declining mortality from bladder cancer in Europe. BJU Int 2008; 101(1): 11 19. doi: 10.1111/j.1464-410X.2007.07239.x

42. Cumberbatch MG, Rota M Catto JWF et al. The role of tobacco smoke in bladder and kidney carcinogenesis: a comparison of exposures and meta-analysis of incidence and mortality risks. Eur Urol 2016; 70(3): 458-466. doi: 10.1016/j.eururo.2015.06.042.

43. Freedman ND. Association between smoking and risk of bladder cancer among men and women. JAMA 2011; 306(7): 737-745. doi: 10.1001/jama.2011.1142.

44. Agudo A, Bonet C, Travier N et al. Impact of cigarette smoking on cancer risk in the European prospective investigation into cancer and nutrition study. J Clin Oncol 2012; 30(36): 4550-4557. doi: 10.1200/JCO.2011.41.0183. 45. Tobacco use in Canada. Current smoking prevalence. [online]. Available from: https://uwaterloo.ca/tobacco-use-canada/adult-tobacco-use/smoking-canada/current-smoking-prevalence.

46. Tobacco in Australia, Facts and Issues. A comprehensive online resource. [online]. Available from: https://www. tobaccoinaustralia.org.au/home.aspx

47. Cancer Research UK. Tobacco statistics. [online]. Available from: https://www.cancerresearchuk.org/healthprofessional/cancer-statistics/risk/tobacco.

48. Vogt A, Schmid S, Heinimann $K$ et al. Multiple primary tumours: challenges and approaches, a review. ESMO Open 2017; 2(2): e000172. doi: 10.1136/esmoopen-2017-000172

49. Coyte A, Morrison DS, McLoone P. Second primary cancer risk - the impact of applying different definitions of multiple primaries: results from a retrospective population-based cancer registry study. BMC Cancer 2014; 14: 272. doi: 10.1186/1471-2407-14-272.

50. Adamo M, Johnson C, Ruhl J et al. SEER program coding and staging manual 2012. Bethesda, MD: National Cancer Institute 2012.

51. Bouchardy C, Lorez M, Clough-Gorr K. Trends in bladder cancer survival in Switzerland. Bull Suisse Cancer 2013; 2: 141-146

52. Ploeg M, Aben KK, Hulsbergen-van de Kaa CA et al. Clinical epidemiology of nonurothelial bladder cancer: analysis of the Netherlands Cancer Registry. J Urol 2010; 183(3): 915-920. doi: 10.1016/j.juro.2009.11.018.

53. Andreassen BK, Grimsrud TK, Haug ES. Bladder cancer survival: women better off in the long run. Eur J Cancer 2018; 95: 52-58. doi: 10.1016/j.ejca.2018.03.001.

54. Ristau BT, Davies BJ. Disparity in bladder cancer outcomes: what's sex got to do with it? Cancer 2014; 120(4): 461-463. doi: 10.1002/cncr.28420. 